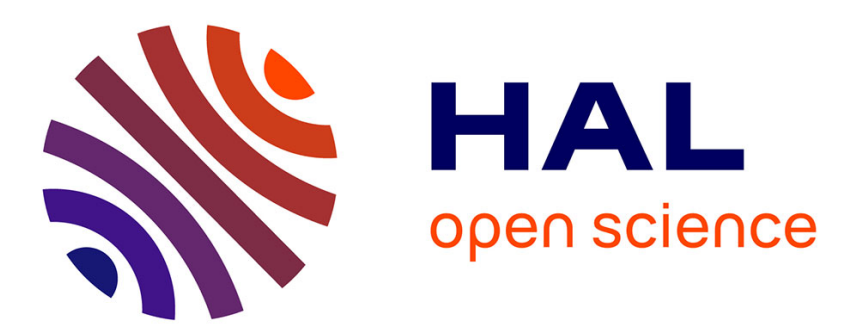

\title{
Distribution of Heteromurus nitidus (Hexapoda, Collembola) according to soil acidity: interactions with earthworms and predator pressure \\ Sandrine Salmon, Jean-François Ponge
}

\section{- To cite this version:}

Sandrine Salmon, Jean-François Ponge. Distribution of Heteromurus nitidus (Hexapoda, Collembola) according to soil acidity: interactions with earthworms and predator pressure. Soil Biology and Biochemistry, 1999, 31 (8), pp.1161-1170. 10.1016/S0038-0717(99)00034-6 . hal-00504091

\section{HAL Id: hal-00504091 \\ https://hal.science/hal-00504091}

Submitted on 19 Jul 2010

HAL is a multi-disciplinary open access archive for the deposit and dissemination of scientific research documents, whether they are published or not. The documents may come from teaching and research institutions in France or abroad, or from public or private research centers.
L'archive ouverte pluridisciplinaire HAL, est destinée au dépôt et à la diffusion de documents scientifiques de niveau recherche, publiés ou non, émanant des établissements d'enseignement et de recherche français ou étrangers, des laboratoires publics ou privés. 
Distribution of Heteromurus nitidus (Hexapoda, Collembola) according to soil acidity: interactions with earthworms and predator pressure.

Sandrine SALMON and Jean François PONGE

Laboratoire d'Ecologie Générale, Museum National d'Histoire Naturelle, 4 Avenue du Petit-Chateau, 91800 Brunoy, France.

Short title: Distribution of Heteromurus nitidus

Number of text pages : 25

5 Tables

2 Figures

Revised on $18^{\text {th }}$ January 99

Softwares used: - Text and tables: Word 97 for Window 95

- Figures: Excel 97 for Window 95

Corresponding author:

Sandrine SALMON

Laboratoire d'Ecologie Générale

Museum National d'Histoire Naturelle

4, Avenue du Petit-Chateau

91800 Brunoy, France

Fax number: +33 160465009

E-mail: ssalmon@mnhn.fr 
Distribution of Heteromurus nitidus (Hexapoda, Collembola) according to soil acidity: interactions with earthworms and predator pressure.

Sandrine SALMON and Jean François PONGE

Laboratoire d'Ecologie Générale, Museum National d'Histoire Naturelle, 4 Avenue du Petit-Chateau, 91800 Brunoy, France.

Summary Culture ( 8 weeks, in sieved fresh humus) and choice (16 weeks in compartmented boxes containing fresh or defaunated humus, or 5 days on compacted humus) experiments at varying $\mathrm{pH}$ levels demonstrated that the soil-dwelling Collembolan Heteromurus nitidus (Entomobryomorpha) can live and even prefer humus with $\mathrm{pH}<5.0$, contrary to results of field studies. Choice experiments on moder $(\mathrm{pH} 7.8)$ and calcic mull $(\mathrm{pH} 3.9)$ showed that $H$. nitidus was significantly attracted by the earthworms Allolobophora chlorotica and Aporrectodea giardi whatever the humus form, except when moder was present on both sides. This attraction by earthworms may partly explain the field distribution of $H$. nitidus. A strong predator pressure was detected in some of the replicates, which seemed to have an impact on densities and distribution of $H$. nitidus, as well. Causes of the attraction by earthworms (food resources, pore size, moisture) are discussed. A trophic cause is particularly suspected. 


\section{INTRODUCTION}

Soil fauna participate, directly or through their action on microflora, to the decomposition of litter and to the building of humus profiles (Ponge et al., 1986). Therefore, the study of the distribution of soil animals is of importance in characterizing soil-forming processes (Ponge, 1983; Arpin et al., 1984). Among the large number of factors (e.g. moisture, temperature, light, depth, food resources), which determine the distribution of soil fauna, humus form (Brêthes et al. 1995) and soil pH have a marked influence on Collembolan communities (Hågvar and Abrahamsen, 1984; Ponge, 1993; Klironomos and Kendrick, 1995). Thus, a number of edaphic Collembolan species may be classified into acid-tolerant and acidintolerant species. However, the effect of $\mathrm{pH}$ is difficult to identify, because this measurement is strongly related to humus form, $\mathrm{C} / \mathrm{N}$ ratio, base saturation and ionic composition of the soil solution. Some relationships have been found previously between the abundance of some Collembolan species and base saturation $(\mathrm{Ca}, \mathrm{Mg}$, and Mn ; Hågvar and Abrahamsen, 1984). In fact, the effect of soil pH can be either direct or indirect. Hågvar (1984) suggested several hypotheses according to which soil acidity could act through ground vegetation, humus form, predator pressure, food resources and competition between species. On the other hand, some experimental studies showed that $\mathrm{pH}$ had a strong effect on activity, fecundity, longevity of adults, and absorption of solutions by the ventral tube (Mertens, 1975; Hutson, 1978; Jaegger and Eisenbeis, 1984).

According to field studies by Ponge (1983, 1993), Heteromurus nitidus (Templeton, 1835), an edaphic Collembola (Entomobryidae), was always found in 
mull humus at $\mathrm{pH}$ above 5. This species, which is readily cultured in the laboratory, was chosen in order to determine whether $\mathrm{pH}$, directly or indirecly, explains H.nitidus field distribution.

In preliminary experiments we attempted to reproduce in experimental vessels the results obtained in the field, i.e. to determine whether $H$. nitidus can live and reproduce only in a humus at $\mathrm{pH}>5.0$ or if this is a behavioural trait. Results suggested that earthworms could be implicated in the distribution of $H$. nitidus. This hypothesis was further tested by giving $H$. nitidus a choice between humus containing or not containing earthworms. The impact of predators was taken into account in the analysis of results, since it appeared to interact with the above mentioned factors.

\section{MATERIALS AND METHODS}

\section{Preliminary field study}

A preliminary study was carried out in the field to see whether $H$. nitidus was located only in soils at $\mathrm{pH} \geq 5.0$ (Ponge, 1993), when a choice between soils at different $\mathrm{pH}$ levels was offered. The distribution of other Collembolan species present in the samples was also studied.

Sixty samples were taken in a plot located in the Senart forest near Paris (France). The soil was a silt-clay loam with a mull humus form under oak (Quercus petraea), with understory vegetation composed of lime (Tilia cordata), hornbeam 
(Carpinus betulus) and bramble (Rubus ulmifolius). Varying conditions of soil acidity have been recorded on this plot, due to the presence of small limestone grains within a patch approximately $3 \mathrm{~m}$ diam from which bramble was absent. Twenty samples of soil+litter were taken with a spade in the central zone without bramble, and forty samples were taken in the surrounding more acidic zone with bramble. Soil arthropods were extracted by the dry-funnel method, i.e. animals escape from the drying sample and are collected at the bottom of a funnel into which they fall. Determination of Collembola was made at the species level, using a dissecting microscope (x40) for larger individuals, and under a light microscope (x400) for smaller ones. Soil $\mathrm{pH}$ was measured in a soil/water mixture $(1: 2 \mathrm{w} / \mathrm{w})$. Data (i.e. presence of species) were analysed by correspondence analysis (Greenacre, 1984). This multivariate method permits the simultaneous representation of samples and species (together with additional variables such as $\mathrm{pH}$ ) into a plane formed by the first two factorial axes.

\section{$\underline{\text { Preliminary culture experiments }}$}

The specimens of H.nitidus used in all the experiments arose from cultures on water-moistened Fontainebleau sand (pure fine quartz sand), fed with a mixture of terrestrial microalgae (Pleurococcus) and lichens taken from bark scrapings. All cultures, as well as boxes for choice experiments, were kept at $15^{\circ} \mathrm{C}$, under a $10 \mathrm{~h}: 14 \mathrm{~h}$ light:dark photoperiod.

Two culture experiments, each made of two series of five and three replicates (one replicate $=$ one box), respectively, were performed using three different types of 
humus: a calcic eumull ( $\mathrm{pH}$ 7.2-7.4), an oligomull ( $\mathrm{pH}$ 4.0-4.6), and an eumoder ( $\mathrm{pH}$ 4.0-4.3). Classification of humus forms follows Brethes et al. (1995). The eumoder and the oligomull came from the Senart forest and the calcic eumull came from the laboratory park (black rendzina under hornbeam). Sampling sites have been described by Arpin et al. (1984) and Bouché (1975). Fifteen adult or sub-adult $H$. nitidus (i.e. specimens $1.8-2.4 \mathrm{~mm}$ in length according to Krool and Bauer, 1987) were introduced into circular plastic boxes $(8 \mathrm{~cm}$ diam, $5 \mathrm{~cm}$ height) filled with fresh roughly sieved $(10 \mathrm{~mm})$ humus. In one series the individuals were fed with lichens and microalgae, in the other no food was added. The purpose of this food/no food comparison was to detect a possible trophic effect on population densities. Cultures were kept at $15^{\circ} \mathrm{C}$ for 9 weeks, so that $H$. nitidus could reproduce several times (about 3 weeks for an egg-to-egg cycle). Animals were then extracted and counted and humus $\mathrm{pH}$ was measured as described above.

H. nitidus individuals were counted in all replicates. Within each experimental run, mean numbers of animals in the different substrates were compared by one-way ANOVA (Sokal and Rohlf, 1995). Data were log-transformed because the reproduction of animals is a non-linear phenomenon, the variance of abundances being proportional to their mean. When significant differences among humus forms were detected, then means were compared by the Newman-Keuls procedure (Sokal and Rohlf, 1995). The two distinct experimental series were treated separately because humus sampling was not made at the same time.

Another culture experiment, with three replicates, was performed on sphagnum moss from the Senart forest. Sphagnum moss is acid ( $\mathrm{pH}$ 4.0) like 
eumoder $(\mathrm{pH} 4.0-4.3)$ but it is poorer in food resources for Collembola (i.e. absence of animal faeces and humified organic matter). Fifteen adult $H$. nitidus were placed on sphagnum moss, in the same boxes as above and were kept for 9 weeks at $15^{\circ} \mathrm{C}$. The number of individuals was counted at the end of the experiment.

\section{$\underline{\text { Preliminary choice experiments }}$}

Choice experiments were carried out in rectangular boxes $(12 \mathrm{~cm} \mathrm{x} 18 \mathrm{~cm} \mathrm{x}$ $6.5 \mathrm{~cm})$ divided into three compartments by perforated plastic walls. Holes $(2 \mathrm{~mm}$ diam) allowed free movement by adult $H$. nitidus. The boxes were placed in a chamber maintained at $15^{\circ} \mathrm{C}$ with a $10 \mathrm{~h}: 14 \mathrm{~h}$ day:night photoperiod.

In a first experiment, with three replicates, a fresh sample block of each humus form, (i.e. oligomull, eumoder or calcic eumull), was placed in each compartment, the position of the humus changing from a box to another. Eight subadult or adult animals were placed in each compartment, thus 24 individuals were present in each box. After 9 weeks fauna were extracted separately from each block of humus. No additional food was supplied. Abundances of $H$. nitidus in each compartment were log-transformed and means were compared between humus forms using two-way ANOVA with experimental boxes as blocks. Humus $\mathrm{pH}$ was measured at the end of the experiment. The same experiment was performed with airdried (ambient temperature, 5 months) then remoistened (with deionized water) humus in order to reduce to a minimum pre-existing fauna without inducing deep changes in humus characteristics (e.g. pH, organic matter). 
A third experiment was performed using the same boxes, but filled with sieved and compacted humus in such a way that $H$. nitidus could not sink in it. This allows continuous counting of surface located collembola. Seven sub-adults or adults were placed in each of the three humus blocks, thus 21 individuals were present in each box. The abundance of $H$. nitidus in each compartment was recorded 3 times a day (at $8 \mathrm{~h}, 13 \mathrm{~h}$ and $18 \mathrm{~h}$ ) for $5 \mathrm{~d}$. Between counting periods boxes were incubated at $15^{\circ} \mathrm{C}$. Means of the fifteen countings for each humus form and each box were compared as described above. A fourth experiment was performed, using fresh humus blocks (six replicates), as in the first experiment. $H$. nitidus could only chose between the two humus forms which differ the most by their $\mathrm{pH}$, i.e. eumoder and calcic eumull. Thirty adult or sub-adult $H$. nitidus were evenly distributed on both humus blocks within each of the six boxes. These were kept for $7 \mathrm{~d}$ at $15^{\circ} \mathrm{C}$, a period too short for the reproduction of animals, which facilitated counting and avoided logtransformation of the data. Animals were extracted separately from each block. Humus $\mathrm{pH}$ was measured as above. H. nitidus were counted as were potential predators of Collembola, i.e. Chilopoda, Pseudoscorpionida, Araneida, and Formicida (Vannier, 1971; Manley et al., 1976; Bachelier, 1978). The presence of other fauna (e.g. other collembola species, oribatid mites, Isopoda, Diplopoda) was noted. Ranked abundances of $H$. nitidus were compared by Kruskal-Wallis test (Sokal and Rohlf, 1995). Without reproduction, abundances were too small to allow variance analysis. Differences in predator numbers between eumoder and calcic eumull were tested by the same method. 


\section{Choice experiments with earthworms}

The aim of these experiments was to discover if $H$. nitidus preferred humus blocks with and without earthworms, independantly of $\mathrm{pH}$ or humus form (eumoder or calcic eumull).

Experimental boxes were divided into two compartments by $1 \mathrm{~mm}$-mesh wire net to minimize the possibility of earthworms moving from one compartment to the other. Compartments were filled with blocks of fresh, non sieved humus. Earthworms were collected in the calcic eumull by expelling them with $4 \%$ o formalin. The lumbricid community was dominated by Allolobophora chlorotica (Savigny, 1826), a small (50mm), endogeic (soil-dwelling and feeding species) and Aporrectodea giardi (Savigny, 1826), a large (150 mm) anecic (soil-dwelling species feeding nightly on litter; Sims and Gerard, 1985). Both species are neutrophilic and live in soil with little organic matter, but $A$. giardi is more tolerant to acidity than $A$. chlorotica (Bouché, 1972). Because of their large size, we added only one adult $A$. giardi to one or both compartments. In one of the experiments, we used two adult $A$. chloratica together with one adult $A$. giardi. All earthworms which had been found by hand-sorting in humus blocks during field sampling were discarded before the experimental run. Combinations between humus forms and presence or absence of earthworms were tested with six replicates each. Thirty adult $H$. nitidus were added to each box at the same time earthworms were introduced. Collembola individuals were distributed in equal number in both compartments. After seven days at $15^{\circ} \mathrm{C}$, animals were extracted in each compartment separately. The abundance of $H$. nitidus was estimated as well as that of total predators. 
Differences between mean abundances of $H$. nitidus and predators with regard to presence or absence of earthworms and to humus form were tested by KruskalWallis test.

\section{RESULTS}

\section{Preliminary field study}

Table 1 lists the 27 Collembolan species found during the field investigation. Results of correspondence analysis (Fig. 1) indicate that soil $\mathrm{pH}$, although not involved as a main variable in the analysis, was strongly correlated with axis 1 , with a highly significant coefficient of determination $\mathrm{R}^{2}(\mathrm{P}<0.001)$. Thus the Collembolan community reflects well the distribution of $\mathrm{pH}$ throughout the sampling area, ranging from 3.9 to 7.4. Axis 1 shows the distribution of several Collembolan species according to soil $\mathrm{pH}$. Axis 2 has no ecological significance. Sminthurinus signatus was located in more acidic sites, while $H$. nitidus, Pseudosinella decipiens, P. alba, and Folsomides parvulus preferred higher $\mathrm{pH}$ soils. Only three $H$. nitidus individuals were found in all our samples, all at $\mathrm{pH} 6$ or above. These results corroborated previous field studies (Ponge, 1993).

\section{$\underline{\text { Culture experiments }}$}

Culture experiments without food supply revealed that $H$. nitidus reproduces and survives at $\mathrm{pH} \leq 5.0$ and even better than at $\mathrm{pH}>5$, i.e. in oligomull and eumoder (Table 2). The population in the eumoder ( $\mathrm{pH} 4.0$ to 4.2 ) was three to four times 
more abundant than in the calcic eumull ( $\mathrm{pH} 7.2$ to 7.4 ) after 9 weeks rearing. Abundances in the acid mull showed discrepancies between both experiments. However, the experiments were not run at the same time (the one with three replicates was in May, the other was in June) and some changes could have occurred in humus properties, for instance soil $\mathrm{pH}$ varied significantly in the oligomull (F test) between sampling dates. From these first culture experiments we concluded that any possible $\mathrm{pH}$ effect on the field distribution of $H$. nitidus was indirect. In laboratory cultures this species not only tolerates acid $\mathrm{pH}$ but this condition seems to be more favourable to its population dynamics than neutral $\mathrm{pH}$, contrary to observations from field studies.

In cultures with a supply of lichens and microalgae, $H$. nitidus population levels largely exceed those obtained in cultures without any food supply, whatever the $\mathrm{pH}$ (Table 2). There were no significant differences between the three humus forms. However, in the experiment with three replicates, the highest abundance of $H$. nitidus was in the calcic eumull. Nevertheless, the residual error was so high and the degrees of freedom were so small that no difference was significant. The fact that the influence of humus form disappeared or changed when food was added may nevertheless suggest that, more important than humus form and acidity, trophic factors are involved in the distribution of $H$. nitidus.

In cultures on sphagnum, there were very few $H$. nitidus $(3.7 \pm 1.1$ individuals per box) and only adult animals were recovered, indicating that, in addition to the high mortality rate, no reproduction was occurring. This may be explained by the 
absence of food available to Collembola, and confirms the involvement of a trophic factor in the distribution of $H$. nitidus.

\section{$\underline{\text { Preliminary choice experiments }}$}

Nine weeks choice experiments did not reveal any preference of $H$. nitidus for a given humus form, both on fresh and defaunated substrates (Table 3). The abundance of $H$. nitidus was much higher (x5.5)on defaunated humus than on fresh humus, particularly in the oligomull, probably because of the increasing microflora following remoistening of the air-dried soil (Soulides and Allison, 1961; Scheu and Parkinson, 1994). Given the long duration of this experiment, considerable reproduction occurred, and overpopulation may have masked some choice behaviour. For this reason shorter-term experiments were also performed.

Short-term experiments, where $H$. nitidus were counted three times a day for five days on compacted humus, indicated that this species was found more frequently on eumoder, calcic eumull being the less-preferred humus form (Table 3). These results confirm the results of culture experiments.

Choice experiments on fresh blocks of eumoder and calcic eumull, where $H$. nitidus were counted after seven days, indicated that these animals were significantly more abundant $(\mathrm{P}<0.05)$ in moder $($ mean $\mathrm{pH}=3.9)$ than in calcic eumull (mean $\mathrm{pH}=$ 7.8) which confirmed results from previous three-compartment choices and cultures (Table 4, "preliminary choice experiment"). In one out of six replicates, H. nitidus 
was more abundant in calcic eumull. This box was characterized by the presence of an earthworm.

\section{Choice experiments with earthworms}

When $H$. nitidus could choose between a block with earthworms and a block without earthworms, their numbers were significantly higher in the block with earthworms (Table 4). This choice was independent of the humus form (combinations 1,2,3), except in combinations where eumoder was present in both compartments (combinations 5,6). Thus H. nitidus was attracted by earthworms or at least remained longer after random movement in compartments containing earthworms. When earthworms were present in compartments filled with calcic eumull and eumoder (combination 4), H. nitidus was not significantly more abundant in eumoder. Thus the preference for eumoder is real but less strong than the earthworm effect.

In some replicates we registered a negative relationship between predator and H. nitidus numbers. In one replicate of combination 3 (Table 4), there were a lot of ants (92) in the compartment with eumoder and $A$. giardi, and the abundance of $H$. nitidus decreased, contrary to what was found in other replicates ( 0 or 1 ant). Moreover, replicates of combination 6 showed a significant $(\mathrm{P}<0.005)$ negative correlation between numbers of $H$. nitidus and large centipedes $(>4 \mathrm{~mm})$ in eumoder (Fig.2). There was no significant interaction between centipede abundance and the presence of earthworms (ANOVA). When we compared the number of predators likely to prey on Collembola, i.e. Chilopoda, Pseudoscorpionida, Araneida and 
Formicida, in eumoder and calcic eumull (Table 5), we noted that eumoder accommodated significantly more predators than calcic eumull. The abundance of predators did not seem to have any effect below a certain threshold which has not been reached in the calcic mull (Table 5). Therefore the high abundance of predators of collembola in eumoder (and perhaps in other acid humus forms) could be an additional reason for the absence of $H$. nitidus in soils with $\mathrm{pH}<5.0$.

\section{DISCUSSION}

In contrast to our field results and those of Ponge (1983, 1993), our culture and choice experiments showed that $H$. nitidus prefers acid soils between $\mathrm{pH} 4$ and 5 in which conditions, possibly food resources, are more favourable to its development than in neutral-alkaline soils. From this it follows that soil acidity (at least at $\mathrm{pH} 4$ ), does not have a direct effect on $H$. nitidus. These results are inconsistent with those obtained by Kopeszki (1992) in a field experiment, which indicated that the abundance of $H$. nitidus decreased according to soil $\mathrm{pH}-\mathrm{KCl}$ within the range of 4.5 to 3. However, comparison is difficult because experimental conditions as well as $\mathrm{pH}$ measurements were different and, above all, because in Kopeszki's experiments soil acidification was induced by acid rain, comprising other compounds such as $\mathrm{SO}_{4}{ }^{2-}$ which probably had a greater influence than the pH (Sequeira, 1987). Hågvar (1984) showed that three microarthropod species (including a Collembola species) did not have the same reaction towards soil $\mathrm{pH}$ when they were cultured alone on defaunated soils compared with cultures in natural soils with complete fauna. Our results support the hypothesis that other organisms affect the distribution of $H$. nitidus. 
The presence of $H$. nitidus in neutro-alkaline soils only may be determined by two types of factors: positive factors which attract it to neutro-alkaline and negative factors which prevent it living in acid soils. In our choice experiments we demonstrated that $H$. nitidus moved to compartments with earthworms, the distribution of which is influenced by soil $\mathrm{pH}$ and calcium content (Satchell, 1967; Piearce, 1972a and 1972b). Piearce (1972b) found earthworms were more important (in terms of species richness, population density and biomass) in soils > pH5.0 compared to more acidic soils. Moreover, H. nitidus was always found in soils > pH5.0, thus in mull humus forms. Mull humus forms are rich in earthworms, particularly earthworms belonging to the anecic ecological category (Jabiol et al., 1995), while the lumbricid fauna is poorly represented in moder (Bouché, 1975). Consequently, the distribution of $H$. nitidus in relation to soil $\mathrm{pH}$ is likely to be controlled by the presence of earthworms. However, this relationship is probably species-specific since a number of earthworms are acid-tolerant and inhabit oligomull humus forms at <pH5.0. Aporrectodea giardi and Allolobophora chlorotica, which attracted $H$. nitidus in our choice experiments, are considered neutrophilic and live in soils with little litter (Bouché, 1972). Therefore they will not be present in oligomull. There is little information about Aporrectodea giardi which occupies a very restricted geographic area, while Allolobophora chlorotica is an acid-intolerant species (Piearce, 1972a).

Earthworms have a great impact on the soil environment and therefore the attraction of $H$. nitidus to soils containing earthworms may be due to several causes. Some consider earthworm burrows as a favourable microhabitat for microarthropods, without distinguishing attractive factors (Bayoumi, 1978; Loksa, 1978). A major 
initial impact of burrowing is its effect on soil structure (Satchell, 1967). Soildwelling Collembola are sensitive to soil compaction, and any reduction in soil pore size produces a decrease in Collembola densities (Heisler and Keiser, 1995). Furthermore, larger Collembola are more abundant in zones with high earthworm densities than in zones without or with few earthworms (Marinissen and Bok, 1988; Loranger et al., 1998). Thus earthworm tunnels could allow H. nitidus, a large soildwelling Collembola, to move within the soil profile, either to search for food or to escape unfavourable conditions near the surface. This would be impossible in moder where mineral horizons are compact (Bernier, 1996). Some authors assigned the positive influence of earthworms upon microarthropod populations to improvement in water retention capacity (Hamilton and Sillman, 1989) or drainage (Loranger et al., 1998). However, H. nitidus has never been found in oligomull at <pH5, despite the presence of earthworm burrows.

Our results from culture and choice experiments give more support to a trophic cause for the attraction of $H$. nitidus by earthworms, since their gut contents were mostly made of ingested invertebrate faeces (Arpin et al., 1980; data not presented). Increase in food availability has been evoked often as an explanation for the observed impacts of earthworms upon soil fauna (Brown, 1995; Loranger et al., 1998). Several processes may explain this increase:

(1) Microorganisms. Some bacteria (including actinomycetes) are more abundant in fresh casts than in surrounding soil (Satchell, 1967; Martin and Marinissen, 1993), which implies that $H$. nitidus would have to live in close proximity to earthworms in order to benefit from fresh cast deposition. 
(2) Mineral nutrients. Generally, earthworm casts are richer in total and exchangeable $\mathrm{Ca}^{2+}$, exchangeable $\mathrm{K}^{+}$and $\mathrm{Mg}^{2+}$, inorganic $\mathrm{PO}_{4}{ }^{3-}$, and $\mathrm{NO}_{3}{ }^{-}$(Lunt and Jacobson, 1944; Sharpley and Syers, 1976; Martin and Marinissen, 1993). Acid-intolerant species of earthworms secrete a greater quantity of calcium than others (Piearce, 1972b; Wiecek and Messenger, 1972).

(3) Organic compounds. Casts and burrow walls have generally a higher content in organic matter than surrounding soil, at least in deep horizons (Lunt and Jacobson, 1944; Kretzschmar, 1987). Earthworms excrete a number of organic compounds such as proteins and glycoproteins, urea, amino-acids, vitamins, osides. These are excreted not only in casts, but also directly in the environment through their nephridiae (El Duweini and Ghabbour, 1971), and as epidermal mucus which is considered as an important nitrogen source for soil microorganisms and plants (Needham, 1957; Dubash and Ganti, 1964; Atlavinyte and Daciulyte, 1969; Cortez and Bouché, 1987). These products may be different according to species and some of them, particularly nitrogenous compounds, are susceptible to rapid decomposition, which could necessit a rapid uptake by $H$. nitidus, if this species is capable of using them as food.

It is not known whether $H$. nitidus is attracted to earthworms by chemical signals or merely remains in a beneficial environment after random exploration of the soil. The latter process could be reinforced by aggregation pheromones which have been found in Collembola (Verhoef et al., 1977), including H. nitidus (Krool and Bauer, 1987). It has been demonstrated that some Collembolan species are attracted by odours produced by fungal species on which they feed (Bengtson et al., 1988), which may support the idea of chemoattraction if such odours are produced by 
earthworms. Furthermore, glycoproteins excreted by Lumbricus terrestris have been suspected to induce attack by its predators (Halpern et al., 1984).

The attraction of H. nitidus by earthworms may be a reason why this species is present only in soils at $>\mathrm{pH} 5$ but does not explain why it was not found in oligomull at $<\mathrm{pH} 5$ even though it can be cultured in the laboratory in moder at lower $\mathrm{pH}$. As this research demonstrated, a strong predator pressure has a negative impact on the presence of $H$. nitidus. Furthermore, Vannier (1971) noted that ants capture $H$. nitidus, and spiders and centipedes are among the most important predators of Collembola (Manley et al., 1976). In our samples, all three of these predators were much more abundant in eumoder than in calcic eumull. Thus, predation could explain the absence of this species at $\mathrm{pH}<5$.

Studying the spatial distribution of soil animals is difficult because several factors interact with each other (Ponge et al., 1997). In the case of $H$. nitidus, strong relationships with earthworms seem established but underlying mechanisms remain to be studied, as well as quantification of the impact of predators in the field. 


\section{REFERENCES}

Arpin, P., Kilbertus, G., Ponge, J. F. and Vannier, G. (1980) Importance de la microflore et de la microfaune en milieu forestier. In Actualités d'écologie forestière, ed. P. Pesson, pp. 87-150. Gauthier-Villars, Paris.

Arpin, P., Ponge, J-F., Dabin, B. and Mori, A. (1984) Utilisation des nématodes Mononchida et des collemboles pour caractériser des phénomènes pédobiologiques. Revue d'Ecologie et de Biologie du Sol 21, 243-268.

Atlavinyte, O. and Daciulyte, J. (1969) The effect of the earthworms on the accumulation of vitamin $\mathrm{B}_{12}$ in soil. Pedobiologia 9, 165-170.

Bachelier, G. (1978) La faune des sols, son écologie et son action. ORSTOM, Paris.

Bayoumi, B. M. (1978) Significance of the microhabitat on the distribution of oribatid mites in a hornbeam-oak mixed forest. Opuscula Zoologica Budapest 15, 51-59.

Bengtsson, G., Erlandsson, A. and Rundgren, S. (1988) Fungal odour attracts soil Collembola. Soil Biology and Biochemistry 20, 25-30.

Bernier, N. (1996) Altitudinal changes in humus form dynamics in a spruce forest at the montane level. Plant and Soil 178, 1-28.

Bouché, M. B. (1972) Lombriciens de France. Ecologie et systématique. I.N.R.A. Publ. 72-2, Paris.

Bouché, M. B. (1975) Fonctions des lombriciens. III. Premières estimations quantitatives des stations françaises du P.B.I. Revue d'Ecologie et de Biologie $d u$ Sol 12, 25-44. 
Brêthes, A., Brun, J. J., Jabiol, B., Ponge, J. F., and Toutain, F. (1995) Classification of forest humus forms: a French proposal. Annales des Sciences Forestières 52, 535-546.

Brown, G.G. (1995) How do earthworms affect microfloral and faunal community diversity? Plant and Soil 170, 209-231.

Cortez, J. and Bouché, M. (1987) Composition chimique du mucus cutané de Allolobophora chaetophora chaetophora (Oligochaeta: Lumbricidae). Comptes-Rendus de l'Académie des Sciences de Paris, Série III, 305, 207210.

Dubash, P. J. and Ganti, S. S. (1964) Earthworms and amino-acids in soil. Current Science 7, 219-220.

El Duweini, A. K. and Ghabbour, I. (1971) Nitrogen contribution by live earthworms to the soil. IVth Colloquium Pedobiologiae, 1970, September, Dijon, France, pp 495-501. INRA, Paris.

Greenacre, M. J. (1984) Theory and applications of correspondence analysis. Academic Press, London.

Hågvar, S. (1984) Ecological studies of microarthropods in forest soils, with emphasis on relations to soil acidity. University of Oslo, Oslo.

Hågvar, S. and Abrahamsen, G. (1984) Collembola in Norwegian coniferous forest soils. III. Relations to soil chemistry. Pedobiologia 27, 331-339.

Halpern, N., Schulman, N., Scribani, L. and Kirschenbaum, D. M. (1984) Characterization of vomeronasally-mediated response-eliciting components of earthworm wash. II. Pharmacology, Biochemistry and Behavior 21, 655-662.

Hamilton, W. E. and Sillman, D. Y. (1989) Influence of earthworm middens on the distribution of soil microarthropods. Biology and Fertility of Soils 8, 279-284. 
Heisler, C. and Keiser, E. A. (1995) Influence of agricultural traffic and crop management on collembola and microbial biomass in arable soil. Biology and Fertility of Soils 19, 159-165.

Hutson, B. R. (1978) Influence of pH, temperature and salinity on the fecundity and longevity of four species of Collembola. Pedobiologia 18, 163-179.

Jabiol, B., Brêthes, A., Ponge, J. F., Toutain, F. and Brun, J. J. (1995) L'humus sous toutes ses formes. ENGREF, Nancy.

Jaeger, G. and Eisenbeis, G. (1984) pH-dependent absorption of solutions by the ventral tube of Tomocerus flavescens (Tullberg, 1871) (Insecta, Collembola). Revue d'Ecologie et de Biologie du Sol 21, 519-531.

Klironomos, J. N. and Kendrick, B. (1995) Relationships among microarthropods, fungi and their environment. Plant and Soil 170, 183-197.

Kopeszki, H. (1992) Versuch einer aktiven Bioindikation mit den bodenlebenden Collembolen-Arten Folsomia candida (Willem) und Heteromurus nitidus (Templeton) in einem Buchenwald-Ökosystem. Zoologischer Anzeiger 228, 82-90.

Kretzschmar, A. (1987) Caractérisation microscopique de l'activité des lombriciens endogés. In Micromorphologie des sols. Soil micromorphology, eds. N. Fedoroff, L. M. Bresson, and M. A. Courty, pp. 325-330. AFES, Paris.

Krool, S. and Bauer, T. (1987) Reproduction, development and pheromone secretion in Heteromurus nitidus Templeton, 1835 (Collembola, Entomobryidae).Revue d'Ecologie et de Biologie du Sol 24, 187-195.

Loksa, I. (1978) Mikrohabitate und ihre Bedeutung für die Verteilung der Collembolengemeinschaften in einem Hainbuchen- Eichenbestand. Opuscula Zoologica Budapest 15, 93-117. 
Loranger, G., Ponge, J. F., Blanchart, E. and Lavelle, P. (1998) Impact of earthworms on the diversity of microarthropods in a vertisol (Martinique). Biology and Fertility of Soils 27, 21-26.

Lunt, H. A. and Jacobson, H. G. M. (1944) The chemical composition of earthworm casts. Soil Science 58, 367-375.

Manley, G. V., Butcher, J. W. and Zabik, M. (1976) DDT transfer and metabolism in a forest litter macro-arthropod food chain. Pedobiologia 16, 81-98.

Marinissen, J. C. Y. and Bok, J. (1988) Earthworm-amended soil structure: its influence on Collembola populations in grassland. Pedobiologia 32, 243-252.

Martin, A. and Marinissen, J. C. Y. (1993) Biological and physico-chemical processes in excrements of soil animals. Geoderma 56, 331-347.

Mertens, J. (1975) L'influence du facteur pH sur le comportement de Orchesella villosa (Geoffroy , 1764), (Collembola, Insecta). Annales de la Société Royale de Zoologie de Belgique 105, 45-52.

Needham, A. E. (1957) Components of nitrogenous excreta in the earthworms Lumbricus terrestris L. and Eisenia foetida (Savigny). The Journal of Experimental Biology 34, 425-446.

Piearce, T. G. (1972a) Acid intolerant and ubiquitous Lumbricidae in selected habitats in North Wales. The Journal of Animal Ecology 41, 397-410.

Piearce, T. G. (1972b) The calcium relations of selected Lumbricidae. The Journal of Animal Ecology 41, 167-188.

Ponge, J. F. (1983) Les collemboles indicateurs du type d'humus en milieu forestier. Résultats obtenus au Sud de Paris. Acta Oecologica 4, 359-374.

Ponge, J. F. (1993) Biocenoses of Collembola in atlantic temperate grass-woodland ecosystems. Pedobiologia 37, 223-244. 
Ponge, J. F., Arpin, P., Sondag, F. and Delecour, F. (1997) Soil fauna and site assessment in beech stands of the Belgian Ardennes. Canadian Journal of Forest Research 27, 2053-2064.

Ponge, J. F., Vannier, G., Arpin, P. and David, J. F. (1986) Caractérisation des humus et des litières par la faune du sol. Intérêt sylvicole. Revue Forestière Française 38, 509-516.

Satchell, J. E. (1967) Lumbricidae. In Soil biology, eds. A. Burges and F. Raw, pp259-322. Academic Press, London.

Scheu, S. and Parkinson, D. (1994) Changes in bacterial and fungal biomass C, bacterial and fungal biovolume and ergosterol content after drying, remoistening and incubation of different layers of cool temperate forest soils. Soil Biology and Biochemistry 26, 1515-1525.

Sequeira, R. (1987) The chemical nature of acid precipitation over Europe. Current Science 56, 514-517.

Sharpley, A. N. and Syers, J. K. (1976) Potential role of earthworms casts for the phosphorus enrichment of run-off waters. Soil Biology and Biochemistry 8 , 341-346.

Sims, R. W. and Gerard, B. M. (1985) Earthworms. Keys and notes for the identification and study of the species. Linnean Society of London, London..

Sokal, R. R. and Rohlf, F. J., (1995) Biometry. 3rd edition. W.H. Freeman and Company, New York.

Soulides, D. A. and Allison, F. E. (1961) Effect of drying and freezing soils on carbon dioxide production, available mineral nutrients, aggregation, and bacterial population. Soil Science 91, 291-298. 
Vannier, G. (1971) Les fourmis, prédateurs permanents de certains types de collemboles. Revue d'Ecologie et Biologie du Sol 8,119-132

Verhoef, H. A., Nagelkerke, C. J. and Joosse, E. N. G. (1977) Aggregation pheromones in Collembola (Apterygota), a biotic cause of aggregation. Revue d'Ecologie et de Biologie du Sol 14, 21-25.

Wiecek, C. S. and Messenger, A. S. (1972) Calcite contributions by earthworms to forest soils in northern Illinois. Soil Science Society of America Proceedings 36, 478-480. 


\section{LEGENDS}

Fig. 1 Correspondence analysis on 60 field samples from the Senart forest and 27 Collembolan species. Projection in the plane of axes 1 and 2. Collembolan species are coded by three letters. $\lambda=$ soil with limestone grains, $\bigcirc=$ surrounding acid soil.

Fig. 2 Linear regression between densities of $H$. nitidus and big-size centipedes (>4 $\mathrm{mm}$ ) in combination 6 of choice experiments with earthworms (see text). 
Table 1. List of Collembolan species found in the field study and represented in the correspondence analysis (Fig. 1)

\begin{tabular}{|c|c|}
\hline AFU & Allacma fusca (Linné, 1758) \\
\hline ATE & Arrhopalites terricola (Gisin, 1958) \\
\hline DMI & Dicyrtomina minuta (Fabricius, 1783) \\
\hline EMU & Entomobrya multifasciata (Tüllberg,1871) \\
\hline FMA & Folsomia manolachei (Bagnall, 1939) \\
\hline FPA & Folsomides parvulus (Stach, 1922) \\
\hline HMA & Heteromurus major (Moniez, 1889) \\
\hline HNI & Heteromurus nitidus (Templeton, 1835) \\
\hline IMI & Isotomiella minor (Schäffer, 1896) \\
\hline LCU & Lepidocyrtus curvicollis (Bourlet, 1839) \\
\hline LLA & Lepidocyrtus lanuginosus (Gmelin, 1788) \\
\hline MMI & Megalothorax minimus (Willem, 1900) \\
\hline MMA & Mesaphorura macrochaeta (Rusek, 1976) \\
\hline NMU & Neanura muscorum (Templeton, 1835) \\
\hline OIN & Onychiurus insubrarius (Gisin, 1952) \\
\hline OCI & Orchesella cincta (Linné, 1758) \\
\hline OVI & Orchesella villosa (Geoffroy, 1764) \\
\hline PCA & Paratullbergia callipygos (Börner, 1902) \\
\hline PNO & Parisotoma notabilis (Schäffer, 1896) \\
\hline PAL & Pseudosinella alba (Packard, 1873) \\
\hline PDE & Pseudosinella decipiens (Denis, 1924) \\
\hline SSI & Sminthurinus signatus (Krausbauer, 1898) \\
\hline SIN & Undetermined Symphypleona \\
\hline TBO & Tomocerus botanicus (Cassagnau, 1962) \\
\hline VAR & Vertagopus arboreus (Linné, 1758) \\
\hline XGR & Xenylla grisea (Axelson, 1900) \\
\hline XAR & Xenyllodes armatus (Axelson, 1903) \\
\hline
\end{tabular}


Table 2. Densities of H.nitidus in culture experiments on three humus forms at different $\mathrm{pH}$ values. CM: calcic eumull, AM: oligomull, MO: eumoder. SEM: standard error of the mean. ANOVA was performed on log-transformed data. A posteriori comparisons (Newman-Keuls test) were done at 0.05 level

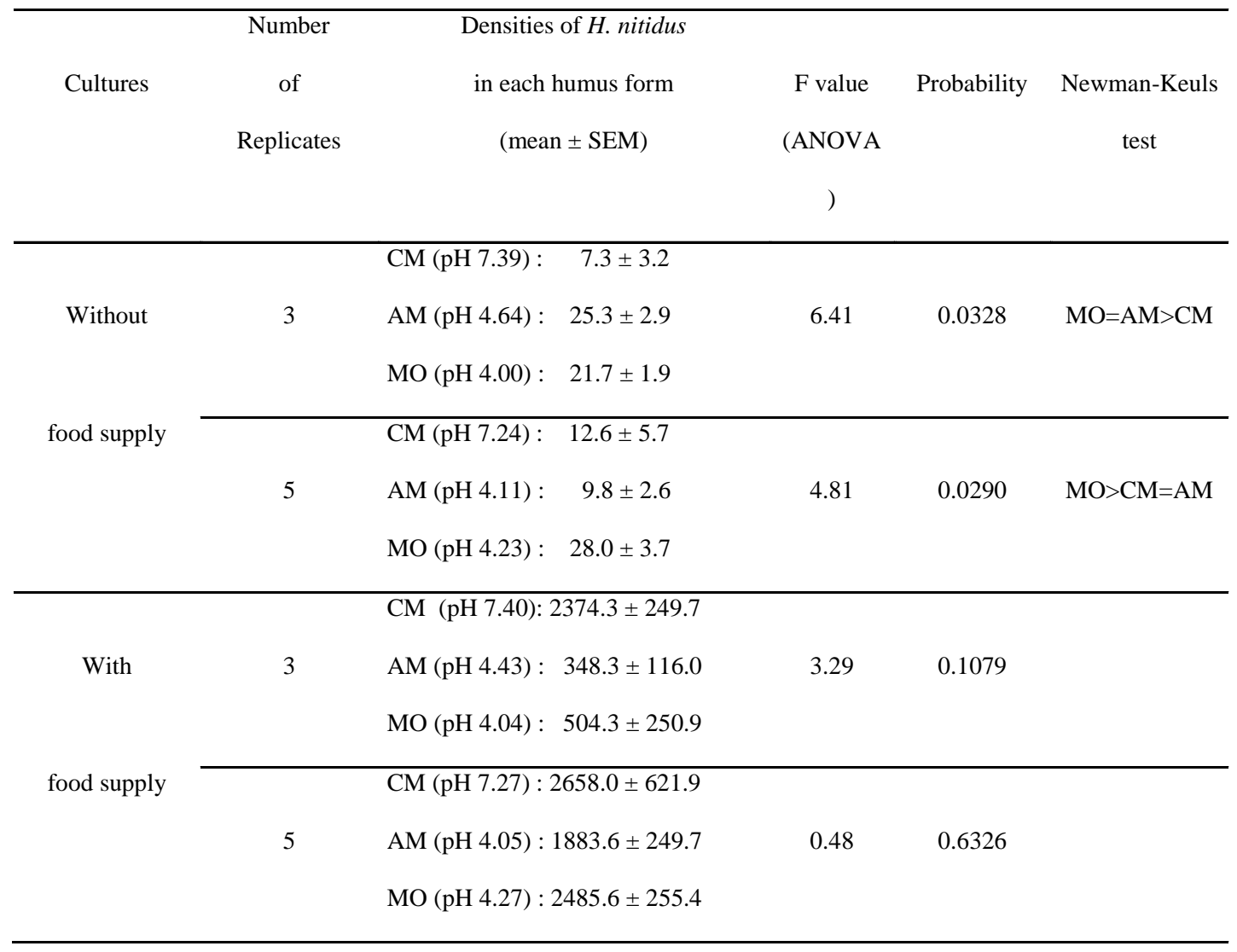


Table 3. Densities of H.nitidus (mean of three replicates) in preliminary choice experiments using three humus forms at different $\mathrm{pH}$ values. $\mathrm{CM}$ : calcic eumull, AM: oligomull; MO: eumoder. SEM: standard error of the mean. A posteriori comparisons (Newman-Keuls test) were done at 0.05 level

\begin{tabular}{|c|c|c|c|c|c|}
\hline \multicolumn{5}{|c|}{ H. nitidus number } & \multirow{3}{*}{ Newman-Keuls } \\
\hline & ice & in each humus type & $F$ value & Probability & \\
\hline \multicolumn{2}{|c|}{ Experiments } & $($ mean \pm SEM $)$ & (ANOVA) & & \\
\hline \multirow{3}{*}{25 H. nitidus } & on fresh & $\mathrm{CM}(\mathrm{pH} 7.51): 54.7 \pm 7.9$ & 0.16 & \multirow{3}{*}{0.8562} & \\
\hline & humus & $\mathrm{AM}(\mathrm{pH} 4.32): 64.0 \pm 22.2$ & (log-transformed & & \\
\hline & & $\mathrm{MO}(\mathrm{pH} 3.87): 40.7 \pm 6.2$ & data) & & \\
\hline \multirow[t]{3}{*}{ for 2 months } & on dried and & $\mathrm{CM}(\mathrm{pH} 7.42): 185.3 \pm 42.0$ & 5.29 & \multirow{3}{*}{0.0763} & \\
\hline & remoistened & $\mathrm{AM}(\mathrm{pH} 4.75): 458.3 \pm 99.7$ & (log-transformed & & \\
\hline & humus & MO (pH4.32) : $250.7 \pm 10.1$ & data) & & \\
\hline \multicolumn{2}{|c|}{$20 \mathrm{H}$. nitidus for 5 days } & $\mathrm{CM}: 4.58 \pm 0.5$ & & & \\
\hline \multirow{2}{*}{\multicolumn{2}{|c|}{ on compacted humus }} & $\mathrm{AM}: 5.96 \pm 0.4$ & 26.35 & 0.000 & $\mathrm{MO}>\mathrm{AM}>\mathrm{CM}$ \\
\hline & & $\mathrm{MO}: 8.64 \pm 0.4$ & & & \\
\hline
\end{tabular}


Table 4. Distribution of $H$. nitidus with regard to the presence of earthworms and to humus form. Each combination was run with 6 replicates and 30 adults. CM: calcic eumull, MO: eumoder, NS: not significant

\begin{tabular}{|c|c|c|c|c|}
\hline \multirow{3}{*}{ Combination } & \multirow{3}{*}{ Blocks } & Densities of $H$. & & \multirow{3}{*}{ Preferred block } \\
\hline & & nitidus (mean of & $\mathrm{X}^{2}$ test & \\
\hline & & replicates/block) & (Kruskal-Wallis) & \\
\hline Preliminary & MO without earthworms & 17 & $\mathrm{P}<0.05(\mathrm{P}<0.01$ without the & $\mathrm{MO}$ \\
\hline choice & $\mathrm{CM}$ without earthworms & 7 & replicate containing an & \\
\hline experiment & except in one replicate & & earthworm in CM) & \\
\hline \multirow[t]{2}{*}{1} & $\mathrm{CM}+\mathrm{A} \cdot$ giardi & 25 & $\mathrm{P}<0.005$ & $\mathrm{CM}+\mathrm{A} \cdot$ giardi \\
\hline & $\mathrm{CM}$ without earthworms & 3 & & \\
\hline \multirow[t]{2}{*}{2} & $\mathrm{CM}+\mathrm{A}$. giardi & 28 & $\mathrm{P}<0.005$ & $\mathrm{CM}+\mathrm{A} \cdot$ giardi \\
\hline & MO without earthworms & 3 & & \\
\hline \multirow[t]{2}{*}{3} & CM without earthworms & 7 & $\mathrm{P}<0.05(\mathrm{P}<0.001$ without the & $\mathrm{MO}+\mathrm{A} \cdot$ giardi \\
\hline & $\mathrm{MO}+\mathrm{A}$. giardi & 19 & replicate containing 92 ants) & \\
\hline \multirow[t]{2}{*}{4} & $\mathrm{MO}+\mathrm{A} \cdot$ giardi & 15 & NS & \\
\hline & $\mathrm{CM}+\mathrm{A} \cdot$ giardi & 9 & & \\
\hline \multirow[t]{2}{*}{5} & $\mathrm{MO}+\mathrm{A}$. giardi & 14 & NS & \\
\hline & MO without earthworms & 9 & & \\
\hline \multirow[t]{3}{*}{6} & $\mathrm{MO}+\mathrm{A} \cdot$ giardi + A. & 17 & NS & \\
\hline & chloratica & & & \\
\hline & MO without earthworms & 12 & & \\
\hline
\end{tabular}


Table 5. Densities of predators (Chilopoda, Pseudoscorpionida, Araneida and Formicida) in choice experiments with regard to humus form and presence of earthworms. Each combination was run with 6 replicates. CM: calcic eumull, MO: eumoder.

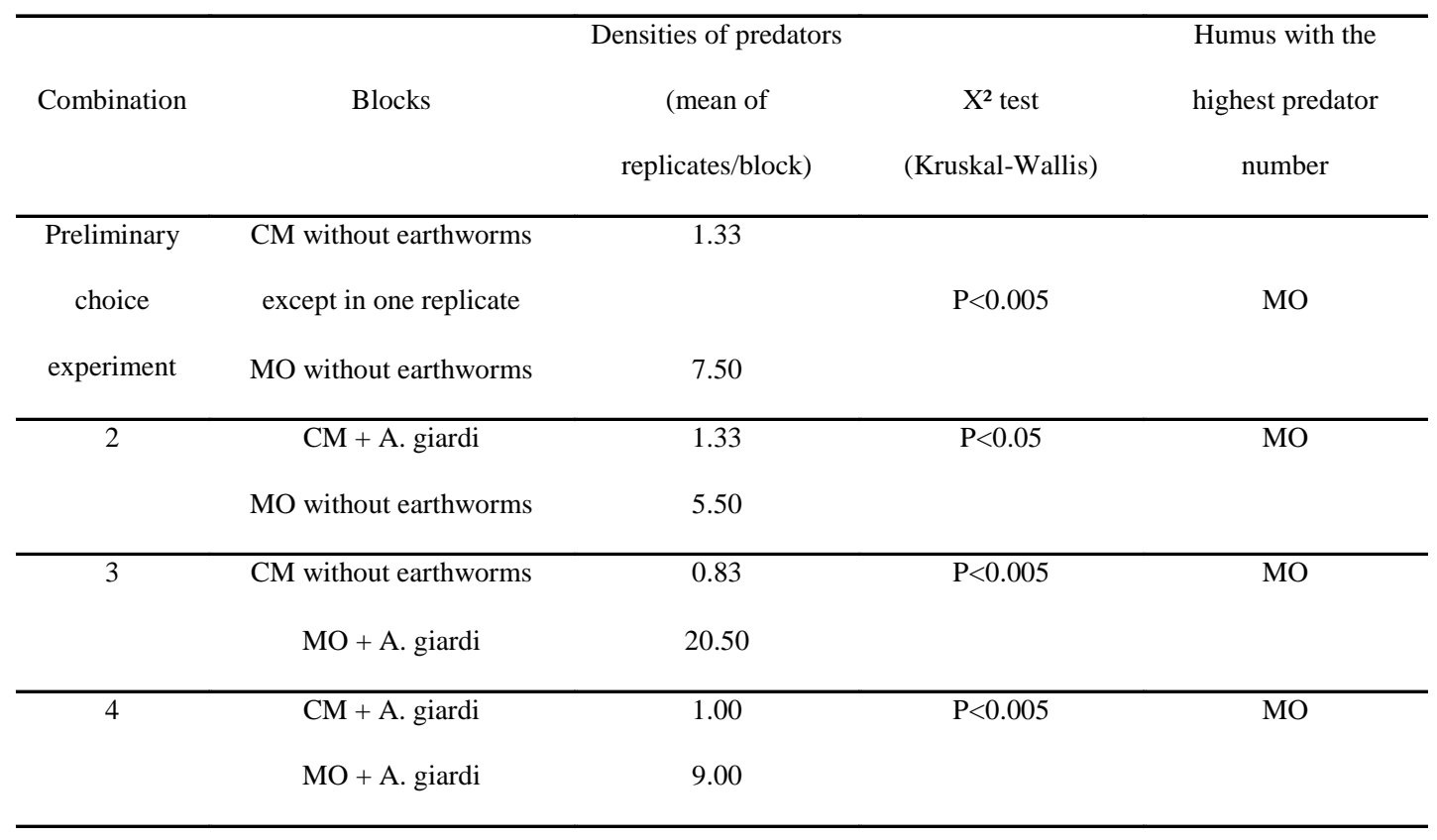


$\infty$

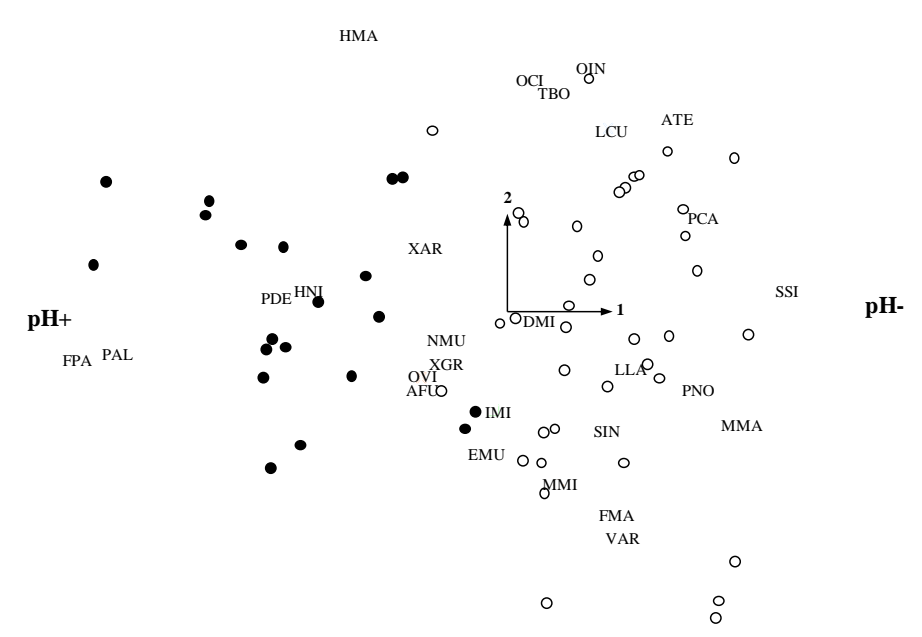

Fig. 1 


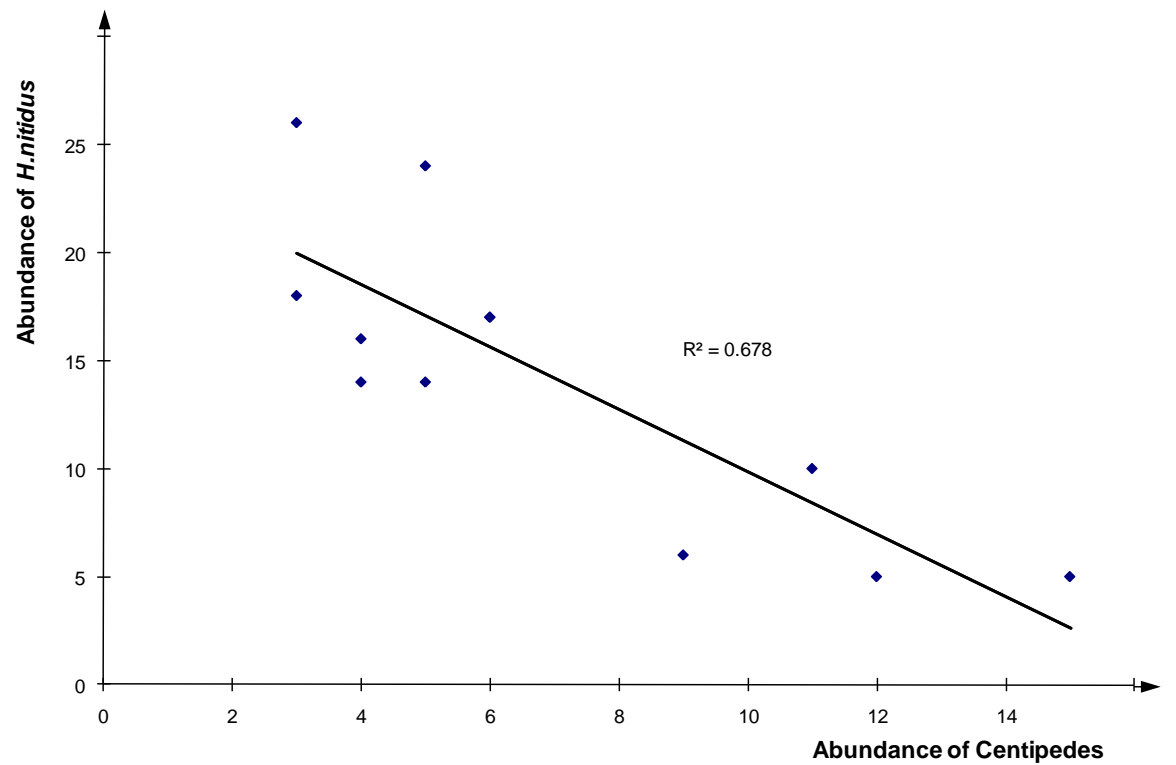

Fig. 2 